\title{
Essential oils and isolated compounds from Lippia alba leaves and flowers: Antimicrobial activity and osteoclast apoptosis
}

\author{
PAULO JOSÉ LIMA JUIZ ${ }^{1}$, ANGELICA MARIA LUCCHESE ${ }^{2}$, ROBERTO GAMBARI ${ }^{3}$, ROBERTA PIVA $^{4}$, \\ LETIZIA PENOLAZZI ${ }^{4}$, MARTINA DI CIANO ${ }^{4}$, ANA PAULA TROVATTI UETANABARO ${ }^{5}$, \\ FRANCELI SILVA $^{6}$ and MARIO JULIO AVILA-CAMPOS ${ }^{7}$
}

\author{
${ }^{1}$ Center for Health Sciences, Federal University of Recôncavo da Bahia, Cajueiro, 44570-000 Santo Antônio de Jesus; \\ ${ }^{2}$ Department of Mathematical Sciences, Area of Chemistry, State University of Feira de Santana, 44031-460 Feira de Santana, \\ Bahia, Brazil; Departments of ${ }^{3}$ Life Sciences and Biotechnology and ${ }^{4}$ Biomedical and Specialty Surgical Sciences, \\ University of Ferrara, 44121 Ferrara, Italy; ${ }^{5}$ Department of Biological Sciences - UESC, State University of Santa Cruz, \\ Salobrinho, 45662900 Ilheus; ${ }^{6}$ Center for Agricultural, Environmental and Biological Sciences, \\ Federal University of Recôncavo da Bahia, 44380-000 Cruz das Almas, Bahia; ${ }^{7}$ Department of Microbiology, \\ Institute of Biomedical Sciences, University of São Paulo, 05508-900 Butantan, São Paulo, Brazil
}

Received July 3, 2014; Accepted October 24, 2014

DOI: 10.3892/ijmm.2014.1995

\begin{abstract}
In the present study, essential oils extracted from the leaves and flowers of Lippia alba (Mill.) N.E.Br. (L. alba) were analyzed for their antimicrobial activity and their effects on osteoclasts. The periodontal pathogens, Aggregatibacter actinomycetemcomitans (A. actinomycetemcomitans; ATCC 43717), Fusobacterium nucleatum (F. nucleatum; ATCC 25586) and Porphyromonas gingivalis (P. gingivalis); ATCC 33277) were used in antimicrobial activity assays for determining the minimum inhibitory concentration (MIC) and the minimum bactericidal concentration (MBC), whereas Bacteroides fragilis (B. fragilis; ATCC 25285) was used as the control microorganism. Osteoclast (OC) apoptosis was assessed by TUNEL assay and Fas receptor expression was detected by immunocytochemistry. The analysis of antimicrobial activity revealed that $P$. gingivalis had the lowest MIC values, whereas A. actinomycetemcomitans had the highest. L. alba essential oils were found to be toxic to human cells, although the compounds, carvone, limonene and citral, were non-toxic and induced apoptosis in the OCs. This study demonstrates that L. alba has potential biotechnological application in dentistry. In fact periodontal disease has a multifactorial etiology, and the immune response to microbial challenge leads to osteoclast activation and the resorption of the alveolar bone, resulting in tooth loss.
\end{abstract}

Correspondence to: Dr Paulo José Lima Juiz, Center for Health Sciences, Federal University of Recôncavo da Bahia, Avenida Carlos Amaral, 1015 Cajueiro, 44570-000 Santo Antônio de Jesus, Bahia, Brazil

E-mail: limajuiz@ufrb.edu.br

Key words: herbal medicine, infection control, oral hygiene, periodontal medicine, preventive dentistry, bone loss

\section{Introduction}

Periodontal disease is among the most common pathological conditions of the oral cavity. It is a predominantly polymicrobial infection and its main consequence is tooth loss, accompanied by esthetic, phonetic and masticatory problems, with significant psychosocial impairment. There is evidence indicating that periodontal disease is a risk factor for cardiovascular diseases (1), stroke (2), pulmonary infections (3) and low birth weight (4). This evidence renders periodontal disease an important public health issue.

The inflammatory process in periodontal disease is triggered and perpetuated by periodontal pathogens. These are Gram-negative anaerobic bacteria, such as Porphyromonas gingivalis ( $P$. gingivalis), Aggregatibacter actinomycetemcomitans (A. actinomycetemcomitans) and Fusobacterium nucleatum (F. nucleatum) (5).

In periodontal disease, bacteria and the products from microbial metabolism, such as butyric and propionic acids, interact with the junctional epithelium, thus enabling the invasion of the underlying connective tissue. This invasion activates an immune response with the consequent production of proinflammatory mediators [interleukin (IL)-1, prostaglandin E2 $\left(\mathrm{PGE}_{2}\right)$ and tumor necrosis factor $(\mathrm{TNF} \alpha)$ ] produced by $\mathrm{T}$ lymphocytes that are present within the periodontal pouch, which promote the differentiation and activation of osteoclasts (OCs), culminating in alveolar bone resorption and consequent tooth loss (6).

The role of the immune system in differentiating and activating OCs is of fundamental importance, particularly the participation of the receptor activator of nuclear factor $(\mathrm{NF})-\kappa \mathrm{B}$ ligand (RANKL), which is present in osteoblasts and cells of the bone marrow stroma and macrophage colony-stimulating factor (M-CSF), which is produced by the bone marrow stroma, osteoblasts and activated T lymphocytes. The co-stimulation of RANKL and M-CSF is important in inducing the differentia- 
tion and activation of OCs, and thus actively participates in the homeostasis of bone tissue (7). Bone resorption induced by OCs is one of the main causes of tooth loss in periodontal disease. Accordingly, the modulation of OC formation and function is suggested as one of the therapeutic targets in the prevention of alveolar bone loss associated with periodontal disease (8).

The clinical procedure most commonly used for treating periodontal disease and/or limiting the damage caused by alveolar bone destruction is root planing and scaling in association with the use of antimicrobial agents. However, studies have reported resistance to antibiotics among periodontal pathogens (9-11). Furthermore, despite proven results, antiseptic substances based on chlorhexidine gluconate present adverse effects that compromise their use for prolonged periods of time. In this regard, the use of medicinal plants may be a promising alternative.

Medicinal plants are potentially useful for preventing and treating periodontal disease, given that an inhibitory effect on the growth of periodontal pathogens has been reported by some studies, from the use of phytotherapy in vitro $(12,13)$. Therefore, there is an enormous social relevance in studying the effects of these plants on the microbiota of periodontal pathogens and in relation to controlling the activation of OCs, which would lead to preventive control with greater accessibility for the population, at a lower cost.

Lippia alba (Mill.) N.E.Br. (L.alba) is a plant in the family Verbenaceae that is popularly known as bushy matgrass, bushy lippia and pitiona in English, and as erva-cidreira, chá-de-tabuleiro, cidrila, alecrim-selvagem, cidreira-brava, falsa-melissa, erva-cidreira-de-campo, salva, salva-do-brasil, salva-limão, alecrim-do-campo, salva-brava and sálvia in Portuguese (14). This plant is considered to be the second most commonly used medicinal plant in the state of Bahia, Brazil. It is used for sedation, hypertension, flatulence and pain relief $(15,16)$. It is also abundantly present in the southern part of the United States (Florida), and in the northern parts of Argentina, India (17) and Australia (18).

The first major objective of the present study was to investigate whether essential oils from L. alba display in vitro antibacterial activity against periodontal pathogens, such as $P$. gingivalis, A. actinomycetemcomitans and F.nucleatum, by determining their minimum inhibitory concentration (MIC) and minimum bactericidal concentration (MBC).

Essential oils from L. alba have been also been shown to exert analgesic, anticonvulsant and anti-inflammatory effects (19). These effects may be mainly attributed to the decreased production of pro-inflammatory cytokines, principally through the inhibition of $\mathrm{NF}-\kappa \mathrm{B}$ activation. Furthermore, $\mathrm{NF}-\kappa \mathrm{B}$ plays a critical role in OC biology by regulating the expression of a large number of OC-specific genes through the RANKL/RANK signaling cascade $(20,21)$. On the basis of such evidence, the second major objective of this study was to determine the effects of these essential oils on OCs in terms of the induction of programmed cell death (apoptosis).

\section{Materials and methods}

Plant samples. L.alba was cultivated from March to June 2010, in the Medicinal Plants Garden at the Federal University of Reconcavo of Bahia, located in the municipality of Santo Antônio de Jesus, Bahia, Brazil. Herborization and treatment were carried out according to Mori et al (22). The botanical material collected was deposited in the Herbarium of the State University of Feira de Santana, where it was identified as L. alba (Mill.) N.E.Br. (Verbenaceae) - HUEFS 167949 , according to the Cronquist system (23).

Extraction of essential oils. Steam hydrodistillation was used for the extraction of the essential oils from the dry leaves and flowers. The chemical composition of the essential oils was determined by gas chromatography-mass spectrometry (GC/MS) in a Shimadzu GC-2010 gas chromatograph coupled to a CG/MS-QP 2010 Shimadzu mass spectrometer. (Shimadzu Corp., Kyoto, Japan) The components were identified by comparing the obtained mass spectra with the library of the equipment used, and by comparing the calculated Kovats indices with those found in the literature (24) using a homologous series of hydrocarbons.

Determination of antimicrobial activity against periodontal pathogens. Antimicrobial susceptibility testing was performed according to the CLSI broth macrodilution method M11-A5, with some modifications (25). The bacterial inoculum was prepared by suspending recent colonies of A. actinomycetemcomitans (ATCC 43717), F. nucleatum (ATCC 25586), P. gingivalis (ATCC 33277) and Bacteroides fragilis (B. fragilis; ATCC 25285) in $5 \mathrm{ml}$ of brain-heart infusion (BHI) broth supplemented with hemin $(5 \mu \mathrm{g} / \mathrm{ml})$ and menadione $(1 \mu \mathrm{g} / \mathrm{ml}$ vitamin $\mathrm{K}$ ), followed by incubation under anaerobic conditions $\left(90 \% \mathrm{~N}_{2}\right.$ and $\left.10 \% \mathrm{CO}_{2}\right)$ at $37^{\circ} \mathrm{C}$ for $48 \mathrm{~h}$. After the incubation period, the inoculum was adjusted to $1.5 \times 10^{8}$ colony-forming units $(\mathrm{CFU}) / \mathrm{ml}$. Stock solutions of essential oils $(50 \mathrm{mg} / \mathrm{ml})$, sterilized by membrane filtration $(0.22 \mu \mathrm{m})$ were prepared using $10 \%$ Tween-80 as a solvent. Increasing concentrations of the compounds $(0.00625-3.2 \mathrm{mg} / \mathrm{ml})$ were used for the tests. MIC determination was carried out through medium observation for turbidity and/or the presence of sediment. Chlorhexidine gluconate $0.12 \%$ (Colgate ${ }^{\circledR}$ Periogard) was used as the control. Experiments were carried out in triplicate. Test tubes with no visible growth in the MIC determination step had $10 \mu$ l plated on blood agar supplemented with hemin $(5 \mu \mathrm{g} / \mathrm{ml})$ and menadione $(1 \mu \mathrm{g} / \mathrm{ml}$ vitamin $\mathrm{K})$, and anaerobically incubated $\left(90 \% \mathrm{~N}_{2}\right.$ and $10 \% \mathrm{CO}_{2}$ ) at $37^{\circ} \mathrm{C}$ for $72 \mathrm{~h}$ to determine the $\mathrm{MBC}$.

Cell culture. Human primary OCs were obtained as previously described by Matsuzaki et al (26), with minor modifications. Briefly, peripheral blood (PB) was collected from healthy volunteers after informed consent was obtained. PB mononuclear cells (PBMCs) were obtained from diluted PB (1:2 in Hanks solution), separated by Histopaque ${ }^{\circledR}-1077$ (Sigma, St. Louis, MO, USA) and subsequently grown in DMEM high glucose medium (EuroClone $\mathrm{SpA}$, Milan, Italy) in the presence of M-CSF $(25 \mathrm{ng} / \mathrm{ml})$, RANKL $(30 \mathrm{ng} / \mathrm{ml})$ at $37^{\circ} \mathrm{C}$ in a $5 \% \mathrm{CO}_{2}$ atmosphere for 14 days. To evaluate osteoclastogenesis, staining for tartrate-resistant acid phosphatase (TRAP) was carried out using the Acid Phosphatase Leukocyte (TRAP) kit no. 386 (Sigma), according to the manufacturer's instructions.

Cytotoxicity assay. Mature OCs were plated in 96-well plates and incubated for 3 days both in the presence of essential oils $(5,50$ and $500 \mu \mathrm{g} / \mathrm{ml})$ and the purified compounds, citral, carvone and limonene (Sigma), at 5, 50 and $500 \mu \mathrm{g} / \mathrm{ml}$. 
A 3\% methanol/dimethyl sulfoxide (DMSO) solution was used as a negative control and to solubilize the compounds. The determination of cell viability was carried out following MTT (thiazolyl blue) colorimetric assay. The assay, based on the conversion of the yellow tetrazolium salt, MTT (Sigma), to purple formazan crystals by metabolically active cells, provides a quantitative determination of viable cells. Following $72 \mathrm{~h}$ of treatment (experiments performed in triplicate), $25 \mu \mathrm{l}$ of MTT were added to each well, and the plates were incubated for $2 \mathrm{~h}$ at $37^{\circ} \mathrm{C}$. The medium was removed, and the MTT crystals were solubilized with $50 \%$ dimethylformamide; the spectrophotometric absorbance of each sample was then measured at $570 \mathrm{~nm}$ using a Sunrise ${ }^{\mathrm{TM}}$ Absorbance Reader (Tecan Group Ltd., Männedorf, Switzerland).

Apoptosis (TUNEL assay). At the end of treatment, the cells were rinsed twice with phosphate-buffered saline (PBS) and fixed for $25 \mathrm{~min}$ in $4 \%$ paraformaldehyde at room temperature. Apoptotic cells were detected by the DeadEnd Colorimetric Apoptosis Detection System (Promega, Madison, WI, USA) according to the manufacturer's instructions. Moreover, all cells were subjected to hematoxylin staining, showing blue stained nuclei. The cells were mounted in glycerol/ PBS 9:1 and observed under a Leica microscope (Leica Microsystems GmbH, Wetzlar, Germany). The measurement of apoptosis was calculated as a percentage of apoptotic nuclei (dark brown nuclei) vs. total nuclei of multinucleated TRAPpositive cells, evaluated from 3 experiments.

Immunocytochemistry. Immunocytochemical analysis was performed using an ImmPRESS Universal Reagent kit (Vector Laboratories, Inc., Burlingame, CA, USA). The OCs were seeded in 4-well chamber slides, fixed in cold $100 \%$ methanol and permeabilized with $0.2 \%$ (vol/vol) Triton X-100 (Sigma), in Tris-buffered saline (TBS). The cells were incubated in $0.3 \% \mathrm{H}_{2} \mathrm{O}_{2}$, and the endogenous peroxidase was blocked with ready-to-use $(2.5 \%)$ normal horse serum blocking solution (ImmPRESS reagent kit; Vector Laboratories, Inc.). Following incubation with the primary antibodies (1:500 dilution), specific for the Fas receptor (C-20, rabbit anti-human) and matrix metalloproteinase-9 (MMP-9; H-129, rabbit anti-human) (Santa Cruz Biotechnology, Inc., Dallas, TX, USA) the cells were incubated for $16 \mathrm{~h}$ at $4^{\circ} \mathrm{C}$. After rinsing in TBS, the cells were incubated for $30 \mathrm{~min}$ at room temperature with ImmPRESS reagent (ImmPRESS reagent kit; Vector Laboratories, Inc.) and then incubated with substrate/chromogen mix (ImmPACT ${ }^{\mathrm{TM}}$ DAB; Vector Laboratories, Inc.). After washing, the cells were mounted in glycerol/PBS 9:1 and observed under a Leica microscope (Leica Microsystems $\mathrm{GmbH}$ ).

Statistical analysis. The sample test for equal proportions without continuity correction data was carried out, using the program R version 2.10.1 (Copyright Foundation for Statistical Computing ISBN 3-900051-07-0). A value of $\mathrm{P}<0.05$ was considered to indicate a statistically significant difference.

\section{Results}

Chromatographic profile of essential oils. The chromatographic profile in Fig. 1 shows that the essential oils derived from $L$. alba, citral, carvone and limonene are the most concentrated components (Table I). The essential oil extracted from the leaves of L. alba contained $18.2 \%$ of citral (mixture of neral and geranial), $15.7 \%$ of limonene and $33.7 \%$ of carvone, whereas the oil extracted from the flowers of $L$. alba contained $19.2 \%$ of citral, $16.7 \%$ of limonene and $36.8 \%$ of carvone. The chemotype III of L. alba was studied, according to the study of Hennebelle et al (27).

Antimicrobial activity. Table II shows the antimicrobial activity of the compounds against the periodontal pathogens examined. The lowest MIC values were observed for $P$. gingivalis in the essential oil extracted from $L$. alba leaves (MIC $0.00625 \mathrm{mg} / \mathrm{ml}$ ), when compared with the activity of A. actinomycetemcomitans (MIC $>3.2 \mathrm{mg} / \mathrm{ml}$ ), F. nucleatum (MIC $0.8 \mathrm{mg} / \mathrm{ml}$ ) and B. fragilis (MIC $0.4 \mathrm{mg} / \mathrm{ml}$ ). As regards the essential oil extracted from the flowers, the lowest MIC was again observed for $P$. gingivalis (MIC $0.0125 \mathrm{mg} / \mathrm{ml}$ ), when compared to the activity of A. actinomycetemcomitans (MIC >3.2 mg/ml), B. fragilis (MIC $1.6 \mathrm{mg} / \mathrm{ml}$ ) and F. nucleatum (MIC $0.8 \mathrm{mg} / \mathrm{ml}$ ).

Cytotoxicity. OCs were obtained from $\mathrm{PB}$ and cultured in complete DMEM plus M-CSF and RANKL for 14 days. OC differentiation was examined by TRAP staining (TRAPpositive cells) and by measuring MMP-9 expression (data not shown). In order to determine whether essential oils from L. alba retained any cytotoxic activity, the OCs were treated with increasing amounts $(0.5-500 \mu \mathrm{g} / \mathrm{ml})$ of essential oils (from the leaves and flowers) for up to $72 \mathrm{~h}$, and the viability of the cells was examined by MTT assay. The viability of the OCs was $68 \%( \pm 2.4)$ and $39 \%( \pm 1.5)$ in those treated with $5 \mu \mathrm{g} / \mathrm{ml}$ of essential oil from L. alba flowers and leaves, respectively. Furthermore, the cytotoxicity increased to $75 \%$ when the OCs were incubated with the highest concentration $(500 \mu \mathrm{g} /$ $\mathrm{ml})$. Thus, we considered these essential oils as toxic to OCs. Furthermore, it was confirmed that there was a cytotoxic effect on PBMCs (data not shown). We also verified the effects of the L. alba chemotype III major components, citral, carvone and limonene in the same experimental conditions. Unlike the whole extract, the isolated compounds did not cause any cytotoxic effects on the total cell population (Fig. 2). Only citral at $500 \mu \mathrm{g} / \mathrm{ml}$ was found to induce a significant decrease in cell viability. Based on this evidence, further experiments were performed with all 3 compounds from L. alba at a maximum concentration of $50 \mu \mathrm{g} / \mathrm{ml}$.

L. alba chemotype III components induce apoptosis in OCs. TUNEL assay was performed on mature OCs after $72 \mathrm{~h}$ of exposure to 5 and $50 \mu \mathrm{g} / \mathrm{ml}$ of the abovementioned compounds; the results are shown in Fig. 3. Citral and limonene induced a high level of apoptosis (almost $100 \%$ of apoptotic nuclei) even at a low concentration $(5 \mu \mathrm{g} / \mathrm{ml})$. In the presence of carvone, a significant increase in the number of TUNEL-positive nuclei was observed, mainly at the highest concentrations. These results were confirmed by immunocytochemistry for FAS receptor, a well known apoptosis-related protein (28) whose expression increased (Fig. 3) in the OCs treated with the 3 components at all concentrations. OCs treated only with the vehicle (methanol/DMSO) were used as control cells. 
Table I. Chemical composition of Lippia alba leaves and flowers.

\begin{tabular}{|c|c|c|c|c|c|}
\hline & Compound & $\mathrm{KI}_{\text {lit }}$ & $\mathrm{KI}_{\text {calc }}$ & Leaves (\%) & Flowers $(\%)$ \\
\hline 1 & $\alpha$-thujene & 930 & 931 & 0.2 & 0.6 \\
\hline 2 & 1-Octen-3-ol & 979 & 977 & 0.4 & 0.7 \\
\hline 3 & 6-Methyl-5-hepten-2-one & 985 & 985 & 1.8 & 1.0 \\
\hline 4 & Myrcene & 990 & 992 & 8.3 & 7.8 \\
\hline 5 & Limonene & 1029 & 1029 & 15.7 & 16.7 \\
\hline 6 & $(Z)-\beta$-Ocimene & 1037 & 1040 & 0.2 & 0.2 \\
\hline 7 & (E)- $\beta$-Ocimene & 1050 & 1051 & 0.5 & 0.2 \\
\hline 8 & Linalool & 1096 & 1101 & 1.1 & 1.0 \\
\hline 9 & Nerol & 1229 & 1231 & 2.2 & 0.6 \\
\hline 10 & Neral & 1238 & 1246 & 11.7 & 11.6 \\
\hline 11 & Carvone & 1243 & 1250 & 33.7 & 36.8 \\
\hline 12 & Geraniol & 1252 & 1256 & 2.9 & 2.5 \\
\hline 13 & Geranial & 1267 & 1272 & 6.5 & 7.6 \\
\hline 14 & E-Caryophyllene & 1419 & 1427 & 2.9 & 1.6 \\
\hline \multirow[t]{2}{*}{15} & Germacrene D & 1485 & 1488 & 3.4 & 2.7 \\
\hline & Total identified & & & 91.4 & 91.6 \\
\hline
\end{tabular}

$\mathrm{KI}$, Kovats index; $\mathrm{KI}_{\mathrm{lit}}$, Kovats retention index in literature; $\mathrm{KI}_{\text {calc }}$, calculated Kovats retention index.
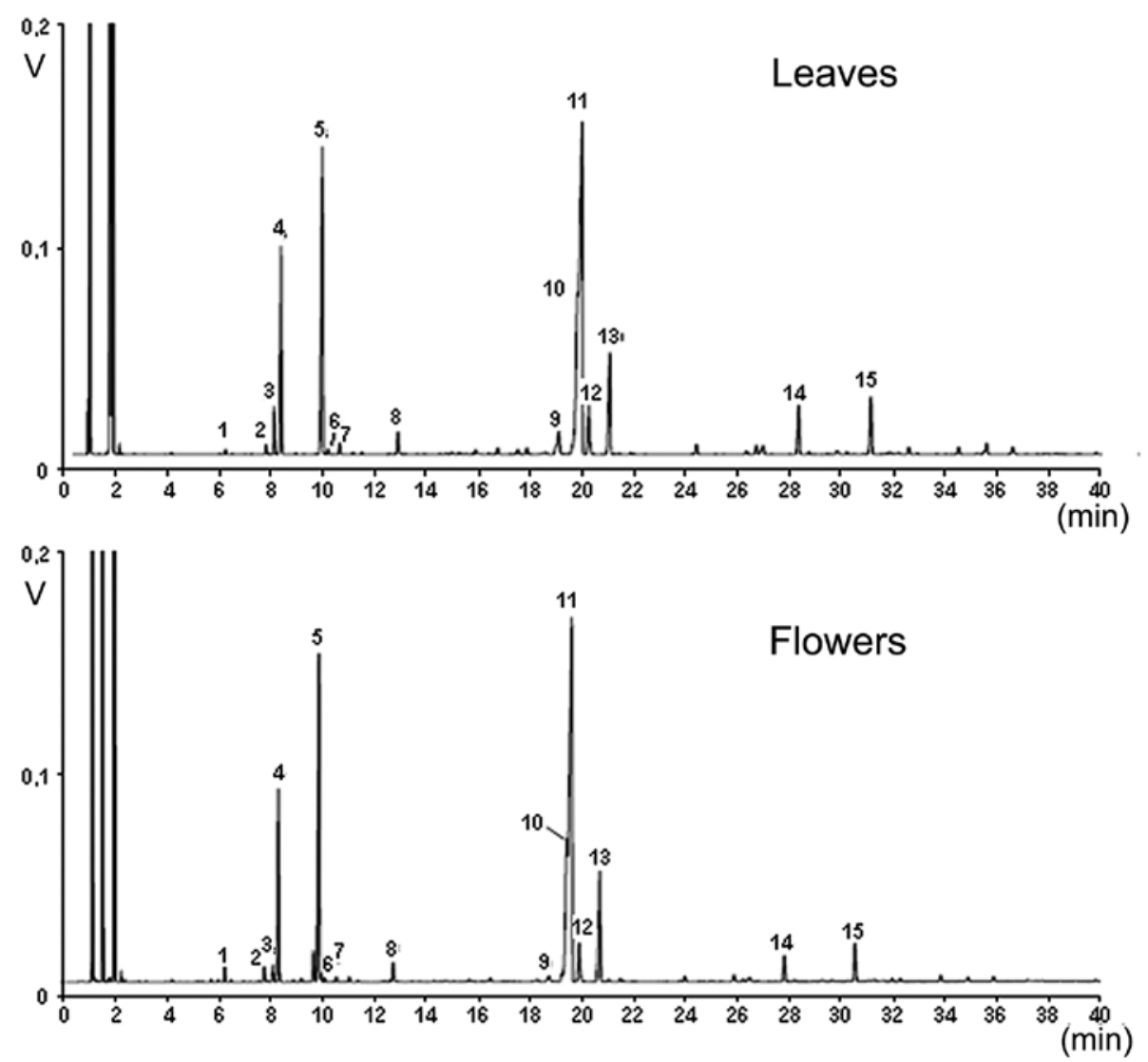

Figure 1. Typical chromatographic profile of essential oils extracted from of Lippia alba (L.alba) leaves and flowers (identification numbers correspond to those reported in Table I).

\section{Discussion}

Natural phytochemicals isolated form plants used in traditional medicine are considered to be a good alternative to synthetic chemicals (29-31). The exploration of botanicals used in traditional medicine may lead to the development of novel preventive 
Table II. Minimum inhibitory concentration (MIC) and minimum bactericidal concentration (MBC) given in $\mathrm{mg} / \mathrm{ml}$ of the essential oil and methanolic extract of Lippia alba against strict anaerobic microorganisms.

\begin{tabular}{|c|c|c|c|c|c|c|c|c|}
\hline \multirow[b]{3}{*}{ Compounds } & \multicolumn{8}{|c|}{ Microorganisms } \\
\hline & \multicolumn{2}{|c|}{ B. fragilis } & \multicolumn{2}{|c|}{ A. $\mathrm{a}^{\mathrm{a}}$} & \multicolumn{2}{|c|}{ P. gingivalis } & \multicolumn{2}{|c|}{ F.nucleatum } \\
\hline & MIC & MBC & MIC & $\mathrm{MBC}$ & MIC & MBC & MIC & $\mathrm{MBC}$ \\
\hline \multicolumn{9}{|l|}{ Essential oil } \\
\hline Lippia alba (leaves) & 0.4 & 0.4 & $>3.2$ & $>3.2$ & 0.00625 & 0.00625 & 0.8 & 1.6 \\
\hline Lippia alba (flowers) & 1.6 & 1.6 & $>3.2$ & $>3.2$ & 0.0125 & 0.0125 & 0.8 & 0.8 \\
\hline \multicolumn{9}{|l|}{ Control } \\
\hline Clorexidin & 0.0075 & 0.0075 & 0.0075 & 0.0075 & 0.001875 & 0.001875 & 0.00375 & 0.00375 \\
\hline Tween-80 10\% & NO & NO & NO & NO & NO & NO & NO & NO \\
\hline DMSO 50\% & NO & NO & NO & NO & NO & NO & NO & NO \\
\hline
\end{tabular}

${ }^{\mathrm{a}}$ Aggregatibacter actinomycetemcomitans. B. fragilis, Bacteroides fragilis; P. gingivalis, Porphyromonas gingivalis; F. nucleatum, Fusobacterium nucleatum; NO, no inhibitory effect was observed; DMSO, dimethyl sulfoxide.

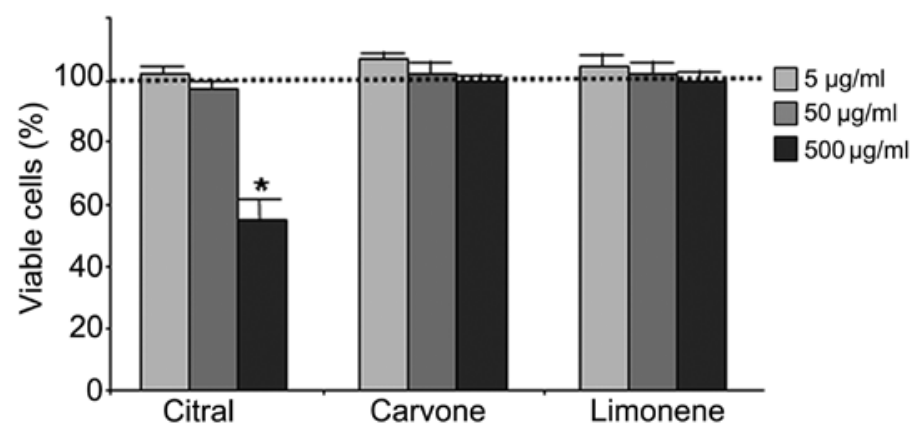

Figure 2. Citotoxicity of Lippia alba chemotype III major components on mature osteoclasts (OCs). The effects of various concentrations (5-500 $\mu \mathrm{g} / \mathrm{ml})$ of citral, carvone and limonene on the viability of osteoclasts (OCs) were measured by MTT colorimetric assay. Results are expressed as a percentage of surviving cells and are the means \pm standard deviation (SD) of 3 independent experiments. The viability of the control cells treated only with the vehicle [methanol/dimethyl sulfoxide (DMSO)] was set at $100 \%$. ( $\mathrm{P}=0.001$ vs. control cells).
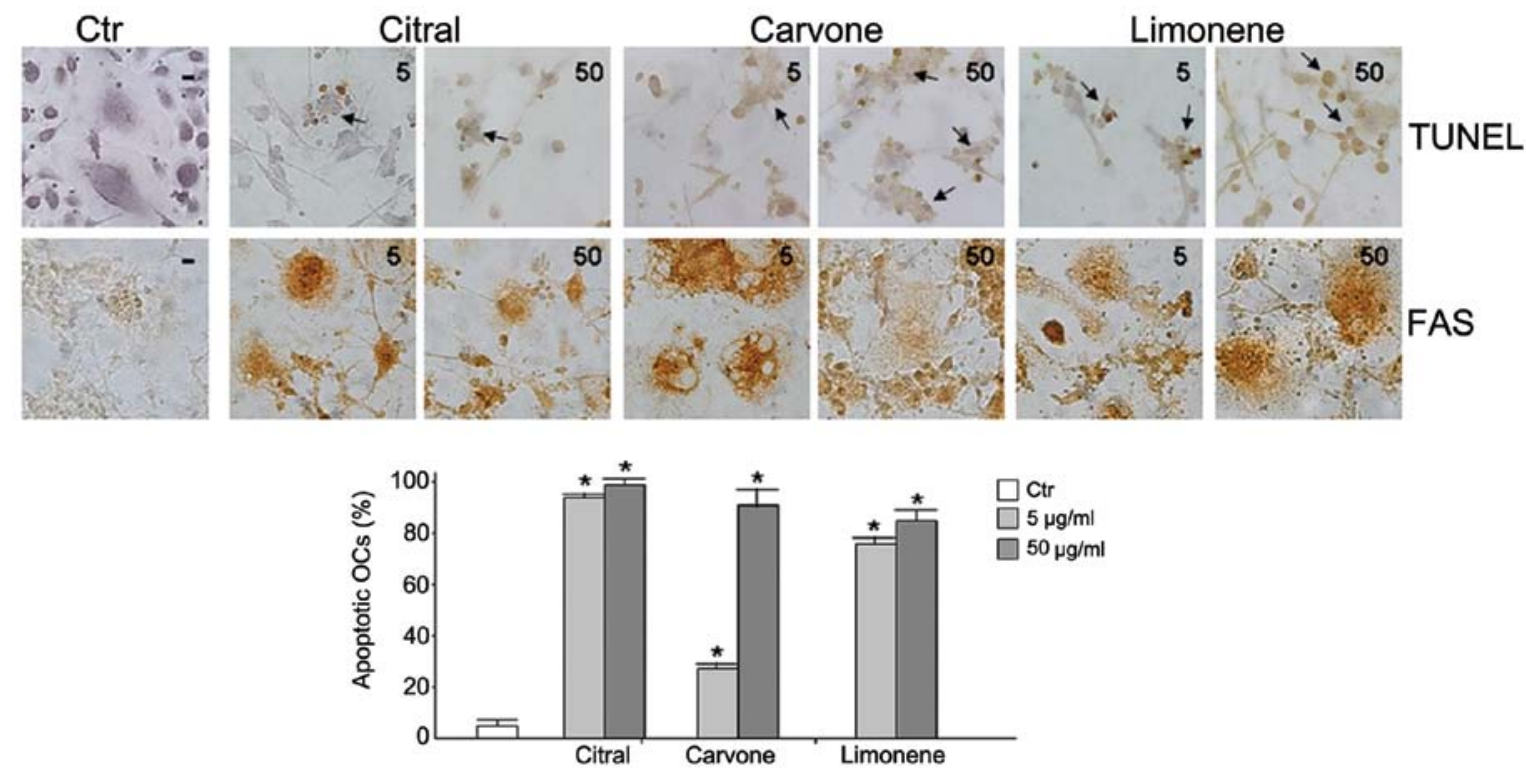

Figure 3. Detection of apoptosis in mature osteoclasts (OCs). Mature OCs were treated for $72 \mathrm{~h}$ with 5 and $50 \mu \mathrm{g} / \mathrm{ml}$ of citral, carvone and limonene. The detection of apoptosis was assessed by TUNEL assay and immunocytochemical staining for FAS receptor (FAS). After TUNEL assay, the cells were counterstained with hematoxylin. Brown color reaction indicates cells that underwent apoptosis. Apoptotic nuclei are indicated by arrows. The dash (-) represents control cells [Ctr, OCs treated with the vehicle, methanol/dimethyl sulfoxide (DMSO)]. The numbers 5 and 50 represent OCs treated with 5 and $50 \mu \mathrm{g} / \mathrm{ml}$ of the corresponding compound, respectively. Magnification, $\mathrm{x} 40$. Quantitative results are presented as a percentage of TUNEL-positive OCs reported in the graph. Data represent the means \pm standard error of the mean (SEM) of 5 independent determinations, for 3 different samples. (" $\mathrm{P}=0.001$ vs control cells). 
or therapeutic strategies for oral health. The aim of this study was to determine whether essential oils from L. alba are useful as potential therapy against periodontal disease. This plant is considered to be the second most commonly used medicinal plant in the state of Bahia, Brazil, and it is widely used in folk medicine in Brazil as for its anti-inflammatory effects.

In this study, we demonstrated that the essential oils extracted from the leaves and flowers of $L$. alba retain an antimicrobial activity against the major Gram-negative periodontal pathogens, such as $P$. gingivalis, $B$. fragilis and $F$. nucleatum. Moreover, they showed no activity against the A. actinomycetemcomitans (ATCC 43717) strain, possibly as it has rapid growth in vitro. We observed that this strain was the most resistant, with an MIC $>3.2 \mathrm{mg} / \mathrm{ml}$.

As has already been reported (32), the use of an antiseptic mouthwash containing essential oils, associated with scaling and root planing, can significantly inhibit the levels of $F$. nucleatum and $P$. gingivalis in supra- and subgingival biofilms. As a consequence, antiseptic mouthwash containing compounds from medicinal plants can complement this conventional periodontal therapy.

Since the antimicrobial activity of medicinal plants is due to the presence of potential bioactive compounds, in the case of $L$. alba, the considerable effect against periodontal pathogens may be explained by the presence of limonene, carvone and citral. According to previous studies, each one of these compounds retains the ability to inhibit Gram-negative bacteria proliferation and has a proven anti-inflammatory effect in different cellular models $(33,34)$.

In order to verify the possible effects of essential oils from L. albia on OC activity, the use of purified compounds is mandatory, in consideration of the toxic effects of essential oils of L. alba on OCs ( $>75 \%)$ and PBMCs (data not shown). The lack of cytotoxicity of purified compounds prompted us to examine their effects on the induction of OC apoptosis and include in our experimental plan, the study of the potential activity of these compounds on bone turnover, particularly on OC behaviour. Moreover, it has been demonstrated that periodontal inflammation not only stimulates osteoclastogenesis but also interferes with the uncoupling of bone formation and resorption, consistent with a pathological process (35). In this study, we verified that different concentrations of limonene, carvone and citral did not cause any cytotoxic effect on the total cell population and induced programmed cell death in human primary OCs. As reported in our study, a high percentage of TUNEL-positive OCs was observed in all experimental conditions. When evaluating the effects of these compounds on OCs, the apoptotic activity was confirmed by the increasing levels of Fas receptor. Hence, we conclude that citral, carvone and limonene are strong inducers of the apoptotic pathway in primary human OCs.

In particular, the interest in citral is also sustained by the patent application WO200419922A1 (36), relating to methods of freshening breath and oral cleansing, together with obtaining bactericidal effects. Interestingly, citral can be delivered as dentifrice, chewing gum, confection, lozenge, mouthwash, mouth spray or edible film containing an effective amount of the compound (37).

Therefore, our study supports the concept that citral has great biotechnological potential for use in the treatment of periodontal disease, as it is non-toxic, as shown by MTT assay, has antibac- terial activity against $P$. gingivalis (38) and is able to induce apoptosis in $100 \%$ of OCs even at low concentrations $(5 \mu \mathrm{g} / \mathrm{ml})$. These results are in agreement with those of Chaouki et al (39), who indicated that citral is able to induce cell cycle arrest in the $\mathrm{G} 2 / \mathrm{M}$ phase with the subsequent induction of apoptosis. Citral is a $\beta$-substituted vinyl aldehyde present in the leaves and fruits of many plants. It is widely used in the food and cosmetics industries due to its flavor and aroma, and it is classified as a safe chemical agent (40). In conclusion, with respect to periodontal diseases, citral is a double-acting compound exhibiting antibacterial activity and a strong induction of OC apoptosis.

In addition to citral, limonene and carvone were also shown to be promising alternatives in the treatment of periodontal disease. These chemicals are volatile monoterpenes that contribute to flavors and aromas in food and pharmaceutical preparations. In folk medicine, as well as in phytotherapy, they are still used as therapeutic agents, for example as a carminative, laxative or as a digestion aid and particularly against infections of the respiratory tract. Limonene has been widely used clinically for the relief of heartburn and has well-established chemopreventive activity against many types of cancer (41). Carvone has also been associated with chemopreventive activity, since it has been found to induce the detoxifying enzyme glutathione S-transferase in several mouse target tissues (42).

In conclusion, the use of natural products in the treatment of diseases may lead to novel therapeutic strategies with lower costs. The compounds that showed activity in this study may be used for formulating a mouthwash, or may even be impregnated in biodegradable chips for insertion into the gingival sulcus of individuals affected by periodontal disease, following scaling and root planing.

This study demonstrated that L. alba, widely used in folk medicine in Brazil, has a potential biotechnological application in drug formulation. In relation to dentistry, epidemiological studies estimate that $90 \%$ of the population has some form of periodontal disease $(43,44)$. Thus, research on periodontitis treatment, whether at the microbiological, genetic or immune level, should always be considered relevant in the search for curative and/or complementary therapeutic methods.

\section{Acknowledgements}

We thank Coordenação de Aperfeiçoamento de Pessoal de Nível Superior (CAPES), Brazil, for the support and assistance during this study.

\section{References}

1. Shoji M, Sato K, Yukitake H, Kondo Y, et al: Por secretion system-dependent secretion and glycosylation of Porphyromonas gingivalis hemin-binding protein 35. PLoS One 6: e21372, 2011.

2. Wu T, Trevisan M, Genco R J, Dorn JP, Faikner KL and Sempos CT: Periodontal disease and risk of cerebrovascular disease: the first national health and nutrition examination survey and its follow-up study. Arch Intern Med 160: 2749-2755, 2000.

3. Bansal M, Khatri M and Taneja V: Potential role of periodontal infection in respiratory diseases - a review. J Med Life 6: 244-248, 2013.

4. Jacob PS and Nath S: Periodontitis among poor rural Indian mothers increases the risk of low birth weight babies: a hospital-based case control study. J Periodontal Implant Sci 44: 85-93, 2014.

5. Darveau RP, Tanner A and Page RC: The microbial challenge in periodontitis. Periodontol 2000 14: 12-32, 1997. 
6. Ishikawa I: Host responses in periodontal diseases: a preview. Periodontol 2000 43: 9-13, 2007.

7. Hasegawa S, Yonezawa T, Ahn JY, et al: Honokiol inhibits osteoclast differentiation and function in vitro. Biol Pharm Bull 33: 487-492, 2010.

8. Di Benedetto A, Gigante DI, Colucci S and Grano M: Periodontal disease: linking the primary inflammation to bone loss. Clin Dev Immunol 2013: 1-7, 2013.

9. Roberts MC: Antibiotic toxicity, interactions and resistence development. Periodontol 2000 28: 280-297, 2002.

10. Ardila CM, Lòpez M and Guzmán IC: High resistance against clindamycin, metronidazole and amoxicillin in Porphyromonas gingivalis and Aggregatibacter actinomycetemcomitans isolates of periodontal disease. Med Oral Patol Oral Cir Bucal 15: e947-e951, 2010

11. Japoni A, Vasin A, Noushadi S, Kiany F, Japoni S and Alborzi A Antibacterial susceptibility patterns of Porphyromonas gingivalis isolated from chronic periodontitis patients. Med Oral Patol Cir Bucal 16: e1031-e1035, 2011

12. Iauk L, Lo Bue AM, Milazzo I, Rapisarda A and Blandino G: Antibacterial activity of medicinal plant extracts against periodontopathic bacteria. Phytother Res 17: 599-604, 2003.

13. Lee JH, Lee JS, Chung MS and Kim KH: In vitro anti-adhesive activity of an acidic polysaccharide from Panax ginseng on Porphyromonas gingivalis binding to erythrocytes. Planta Med 70: 566-568, 2004

14. Lorenzi H and Matos FJA: Plantas Medicinais no Brasil: Nativas e Exóticas. 2nd edition. Instituto Plantarum, Nova Odessa, São Paulo, 2008.

15. Rodrigues ACC and Guedes MLS: Utilização de plantas medicinais no Povoado Sapucaia, Cruz das Almas-Bahia. Rev Bras Pl Med 8: 1-7, 2006 (In Portuguese).

16. Pinto EPP, Amorozo MCM and Furlan A: Conhecimento popular sobre plantas medicinais em comunidades rurais de mata atlantica - Itacaré, BA, Brasil. Acta Bot Bras 20: 751-762, 2006 (In Portuguese).

17. Singh G, Rao GP, Kapoor PS and Singh OP: Chemical constituents and antifungal activity of Lippia alba Mill. leaf essential oil. JMAPS 22: 701-703, 2000.

18. Day MD and McAndrew TD: The biology and host range of Falconia intermedia (Hemiptera: Miridae), a potential biological control agent for Lantana camara (Verbenaceae) in Australia Biocontrol Sci Techn 13: 13-22, 2003.

19. Blanco MA, Colareda GA, van Baren C, Bandoni AL, Ringuelet J and Consolini AE: Antispasmodic effects and composition of the essential oils from two South American chemotypes of Lippia alba. J Ethnopharmacol 149: 803-809, 2013.

20. Novack DV: Role of NF-кB in the skeleton. Cell Res 21: 169-182, 2011.

21. Wittrant Y, Theoleyre S, Couillaud S, Dunstan C, Heymann D and Rédini F: Relevance of an in vitro osteoclastogenesis system to study receptor activator of NF- $\kappa \mathrm{B}$ ligand and osteoprotegerin biological activities Exp Cell Res 293: 292-301, 2004.

22. Mori SA, Mattos Silva LA, Lisboa G and Coradin L: Manual de Manejo do Herbário Fanerogâmico. 2nd edition. Centro de Pesquisas do Cacau, Ilhéus, Bahia, Brazil, 1989.

23. Cronquist A: An integrated system of classification of flowering plasts. In: The Evolution and Classification of Flowering Plants. Columbia University Press, New York, 1981

24. Adams RP: Identification of Essential Oil Components by Gas Chromatography/Mass Spectroscopy. 4th edition, Allured Pub Corp., Carol Stream, IL, 2007.

25. CLSI - Clinical and Laboratory Standards Institute: Methods for antimicrobial susceptibility testing of anaerobic bacteria Approved standard. 7th edition, M11-A5. CLSI - Clinical and Laboratory Standards Institute, Wayne, PA, USA, 2007.
26. Matsuzaki K, Katayama K, Takahashi Y, et al: Human osteoclast-like cells are formed from peripheral blood mononuclear cells in a coculture with SaOS-2 cells transfected with the parathyroid hormone $(\mathrm{PTH}) / \mathrm{PTH}$-related protein receptor gene. Endocrinology 140: 925-932, 1999.

27. Hennebelle T, Sahpaz S, Joseph $H$ and Bailleul F Ethnopharmacology of Lippia alba. J Ethnopharmacol 116: 211-222, 2008

28. Kovacic N, Grcevic D, Katavic V, Lukic IK and Marusic A: Targeting Fas in osteoresorptive disorders. Expert Opin Ther Targets 14: 1121-1134, 2010

29. Fibach E, Prus E, Bianchi N, Zuccato C, et al: Resveratrol: Antioxidant activity and induction of fetal hemoglobin in erythroid cells from normal donors and $\beta$-thalassemia patients. Int J Mol Med 29: 974-982, 2012.

30. Ruimi N, Rwashdeh H, Wasser S, et al: Daedalea gibbosa substances inhibit LPS-induced expression of iNOS by suppression of NF- $\kappa \mathrm{B}$ and MAPK activities in RAW 264.7 macrophage cells. Int J Mol Med 25: 421-432, 2010.

31. Lau FY, Chui CH, Gambari R, et al: Antiproliferative and apoptosis-inducing activity of Brucea javanica extract on human carcinoma cells. Int J Mol Med 16: 1157-1162, 2005.

32. He JY, Qi GG, Huang WJ, et al: Short-term microbiological effects of scaling and root planing and essential-oils mouthwash in Chinese adults. J Zhejiang Univ Sci B 14: 416-425, 2013.

33. Mizrahi B, Shapira L, Domb AJ and Houri-Haddad Y: Citrus oil and $\mathrm{MgCl}_{2}$ as antibacterial and anti-inflammatory agents. J Periodontol 77: 963-968, 2006.

34. Behan JM, Bradshaw DJ, Richards J and Munroe MJ: Flavour compositions. Process PI US patent 20060153959A1. Filed July 13, 2006

35. Belibasakis GN and Bostanci N: The RANKL-OPG system in clinical periodontology. J Clin Periodontol 39: 239-248, 2012

36. Broderick K, Greenberg M, Maxwell J and Stawski B: Breath freshening and oral cleansing product using citral. US Patent 20040253190 A1. Filed August 26, 2003; issued March 11, 2004.

37. Manafi A, Hashemlou A, Momeni P and Moghimi HR: Enhancing drugs absorption through third-degree burn wound eschar. Burns 34: 698-702, 2008.

38. Goyal R and Ananad MK: Antibacterial effect of lemongrass oil on oral microoganisms: an in vitro study. JPSI 2: 41-43, 2013.

39. Chaouki W, Leger DY, Liagre B, Beneytout JL and Hmamouchi M: Citral inhibits cell proliferation and induces apoptosis and cell cycle arrest in MCF-7 cells. Fundam Clin Pharmacol 23: 549-556, 2009.

40. Ress NB, Hailey JR, Maronpot RR, et al: Toxicology and carcinogenesis studies of microencapsulated citral in rats and mice. Toxicol Sci 71: 198-206, 2003.

41. Sun J: D-Limonene: safety and clinical applications. Altern Med Rev 12: 259-264, 2007.

42. Zheng GQ, Kenney PM and Lam LK: Anethofuran, carvone, and limonene: potential cancer chemopreventive agents from dill weed oil and caraway oil. Planta Med 58: 338-341, 1992.

43. Morris AJ, Steele J and White DA: The oral cleanliness and periodontal health of UK adults in 1998. Br Dent J 191: 186-192, 2001.

44. Borrell LN, Burt BA, Gillespie BW, Lynch J and Neighbors H: Periodontitis in the United States: beyond black and white. J Public Health Dent 62: 92-101, 2002. 